\title{
Peertechz
}

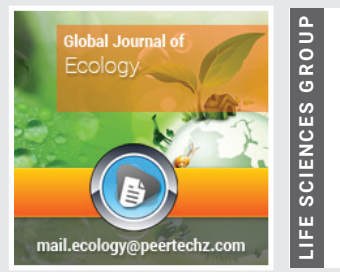

\section{Corallivory and algal dynamics on some coral reefs in the Persian Gulf}

\author{
Javid Kavousi*, Parviz Tavakoli-Kolour ${ }^{2}$ and Sanaz \\ Hazraty-Kari² \\ ${ }^{1}$ University in Brest, CNRS, IRD, Ifremer, LEMAR, F-29280 Plouzane, France \\ ${ }^{2}$ Sesoko Station, Tropical Biosphere Research Center, University of the Ryukyus, Sesoko 3422, \\ Okinawa 905-0227, Japan
}

Received: 10 September, 2020

Accepted: 25 November, 2020

Published: 26 November, 2020

*Corresponding author: Javid Kavousi, University in Brest, CNRS, IRD, Ifremer, LEMAR, F-29280 Plouzane, France, E-mail: javid.kavousi@gmail.com

Keywords: Coral reefs, Macroalgae, Parrotfishes, Fish biting, Massive Porites

https://www.peertechz.com

Check for updates

\begin{abstract}
Macroalgae are a sign of degradation of coral reefs. Distribution of macroalgae on reefs is moderated by grazers including fish and sea urchins. However, several fish species including certain parrotfishes graze on live coral tissues, at times causing profound damage. In this paper, the potential role of macroalgae in suppressing parrotfish predation on Porites corals, the dominant coral genus in Qeshm Island, is investigated at three research sites at Qeshm Island in the Persian Gulf between April and July 2014 and 2015. Macroalgae, which were abundant in April, decreased significantly in frequency in July, while at the same time, the percentage of Porites colonies, the frequency of fish bite marks on Porites colonies, and the overall area of live coral tissue, which was grazed by parrotfishes increased dramatically, all of which were only negligible in April (with certain exceptions). Nevertheless, no changes were observed in parrotfish abundance. Despite partially supportive statistical data, because of the observed exceptions, this phenomenon is more likely to be due to other factors, in particular the increased nutritional values of the corals in July in comparison to April. However, to understand the cause(s) and mechanisms involved in this annual phenomenon, more investigations seem necessary.
\end{abstract}

\section{Introduction}

Macroalgae including fleshy and filamentous algae have been considered serious threats to coral reefs $[1,2]$. Both filamentous algae [3] and macroalgae have negative effects on scleractinian corals, resulting in reef decline through coralalgae shifts, which change scleractinian coral-dominated reefs into macroalgae-dominated reefs $[1,2,4]$. Macroalgae diminish coral reefs by decreasing coral larval settlement, survival, growth rate, fecundity, resilience and recovery, and by causing bleaching and coral mortality $[1,5]$. Macroalgae on coral reefs are moderated by several factors such as physicochemical -e.g. temperature [6] -, geomorphological -e.g. substrate characteristic [7]- or biological -e.g. herbivores [8]-factors. The most important macroalgae-moderators, however, are herbivores, including sea urchin and fish $[8,9]$. In spite of this, corallivorous fishes are a threat to coral reefs themselves $[10,11]$. These fishes reduce coral abundance, diversity and colony size [11], coral expansion and spread, resistance to other stressors and resilience [12] and also increase coral mortality [13].
Although the role of herbivorous fishes in moderating macroalgal assemblies as well as the impact of corallivorous fishes on coral reefs is well documented, there is limited information on the effects of macroalgae on fish corallivory. It was it discerned that under experimental conditions, macroalgae can provide protection for juvenile corals against parrotfishes [14], which are among the most important coral predators preferring massive Porites corals on many reefs [12] and references therein). Moreover, field studies mainly focus on interactions among algae, fishes and juvenile corals (e.g. [15]. Hoey \& Bellwood [16] showed that highly dense macroalgae could repel given fish species including parrotfishes from some reefs. This study implies that if there are any coral colonies among those macroalgal assemblages, they could be sheltered from fish corallivory, this hypothesis still needs to be tested directly.

In this study, field data is gathered to test if macroalgae are involved in moderating parrotfish predations of massive Porites colonies at Qeshm Island, the Persian Gulf. Several parameters, 
including the percentage of coral colonies, the number of fish bites and the area of Porites spp. surface grazed by fishes in correlation to macroalgal cover were analyzed at the three designated research sites during April and July 2014 and 2015 to assess this hypothesis.

\section{Material and methods}

This study was done at the southeast of Qeshm Island $\left(26^{\circ} 45^{\prime} \mathrm{N}, 55^{\circ} 49^{\prime} \mathrm{E}\right)$, situated in the Persian Gulf. Coral reefs in this place are located near-shore, and are mainly less than 6 $\mathrm{m}$ deep dominated by massive Porites spp. for $89 \% \pm 12.2 \%$ (of live coral cover \pm standard deviation) [17]. Three sites, namely 1,2 and 3 were chosen at the two ends as well as the middle of the reef site (Figure 1). Surveys of fish and benthic assemblages were performed in the middle of April, and then again in early July of 2014 and 2015. This time the scale was chosen based on our annual qualitative monitoring method launched in 2009, which includes the month in which grazed corals were abundant (i.e. July) as well as a short period before that when they were scarce (i.e. April).

To estimate benthic communities including grazed Porites and algal cover, five $30 \mathrm{~m}^{-1}$ Line-Intercept transects were established at each site in each month. The only exception was site 3 in July 2014 with only 4 transects due to an unexpected event. We differentiate among Macroalgal (MA) cover, Filamentous Algal (FA) cover, and algal (MA + FA) cover. The number of fishes and Porites colonies grazed by fishes was counted in five $30 * 1 \mathrm{~m}^{-2}$-belt transects for each site. Since the fish bites on the colonies belonged to parrotfishes, we only show the data for this fish. Furthermore, $400 \mathrm{~cm}^{-2}$-photo- quadrates were taken at $1 \mathrm{~m}^{-1}$ intervals along each $30 \mathrm{~m}^{-1}$ transect to assess the frequency and extent of damage from parrotfish bite marks on Porites colonies between April and July. To this end, fish bites of parrotfishes were categorized into spot bites (i.e. individual, superficial bites) and focused bites (i.e. repeated overlapping deep bites resulting in extensive live tissue removal) [18]. The number of spot fish bites and the area of both spot and focused bites on Porites surfaces were counted and estimated using the software CPCe [19].

From April 2015, we calculated the number of bites of $S$. persicus on both Porites corals and algae $\min ^{-1}$ [20], in three month intervals.

As the data sets did not meet the assumptions of parametric tests, and transformations did not work, the non-parametric Kruskal-Wallis test was applied to compare each factor among the sites in each month. Also, the Mann-Whitney U test was utilized for pairwise comparisons. We used the HolmBonferroni method (Holm 1979) to correct the $p$ values to test the respective significant differences in each site between the months. The Significance level, was set at 0.05. Either the Pearson correlation test (when data sets were normally distributed) or the Spearman rho test was used to investigate the relationships between each type of algal groups (MA, FA or AL cover) and other factors. Statistical analyses were performed using SPSS (ver. 22) [21].

\section{Results}

\section{Fish dynamics}

There were only two species of parrotfishes present at

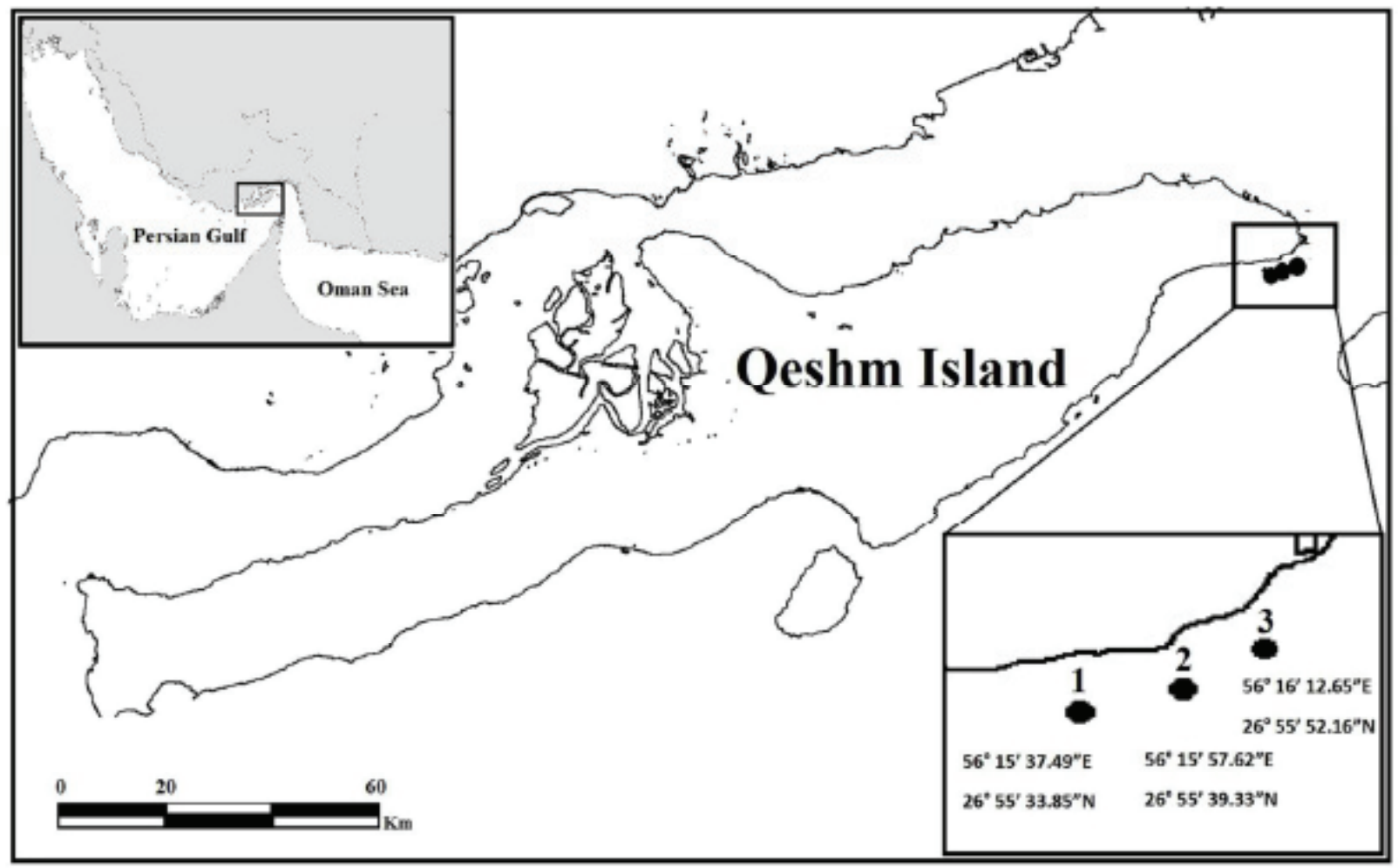

Citation: Kavousi J, Kolour PT, Kari SH (2020) Corallivory and algal dynamics on some coral reefs in the Persian Gulf. Glob J Ecol 5(1): 122-128. DOI: https://dx.doi.org/10.17352/gje.000031 
the studied sites viz. Scarus ghobban and S. persicus. The abundance of S. ghobban was extremely low at all three study sites in both sampling years (in average <0.2-0.6 individual transect-1). However, S. persicus was abundant in all the sites. In 2014, none of the fish species (Figure 2A,B) or size classes (not shown) showed any significant differences in number between the sampling months at each individual site. In 2015, both species showed significantly higher abundance in Site A in April (Figure 2C,D). Both fish species, size class $20 \mathrm{~cm}$ showed significantly higher abundance in April 2015 than in July. However, no difference was recorded for other size classes.

\section{Benthic dynamics}

In 2014, AL, MA and FA cover showed a significant decline in all sites in July compared to April, except AL and FA cover for site B (Figure 3A-C). In 2015, AL and FA did not differ significantly in site A; however, MA cover in Site A and AL, MA and FA cover in the other two sites significantly declined in July (Figure $4 \mathrm{~A}-\mathrm{C}$ ). On the other hand, the other factors significantly increased in July compared to April in all sites in 2014 (Figure 3D-F) and in sites B and C in 2015 (Figure 4D-F). However, the percentage of live coral grazed and the number of spot fish bite marks m-2 were higher in April at site A in 2015.

Correlational analyses between algal cover (including $\mathrm{AL}$, MA and FA cover) and fish grazing related factors (including the percentage of Porites colonies, the frequency of fish bite marks on Porites colonies, and the overall area of live coral tissue, which was grazed by parrotfishes) at site level in 2014 and 2015 did not show significant relations (Tables 1,2). At transect level, however, there were significant negative relationships between MA and other factors in both years, except between MA and the frequency of fish bite marks in 2015 (Tables 1,2). Such correlational tests when considering sites and transects showed non-significant relationships between either AL cover and fish grazing related factors or FA cover and fish grazing related factors.

\section{Discussion}

The results of this study invoke the question whether marine algae protected Porites colonies from parrotfishes in Qeshm Island. The results in both sampling years, 2014 and 2015, mainly showed increased fish grazing on Porites corals when the coverage of algae decreased. However, the correlational tests represented mixed results. The nonsignificant relationships at the site level in both yearssuggest that there was not enough evidence to confirm this hypothesis. On the other hand, correlational data, when considering transects, support the role of MA (but not FA or both MA and FA combined) in reducing the impacts of parrotfish grazing on the corals. This is backed by previous observations at the same sites. In September 2009, although macroalgae completely disappeared, short filamentous algae prevailed. Simultaneously, severe fish biting on more than $80 \%$ of the Porites colonies could be observed [17].
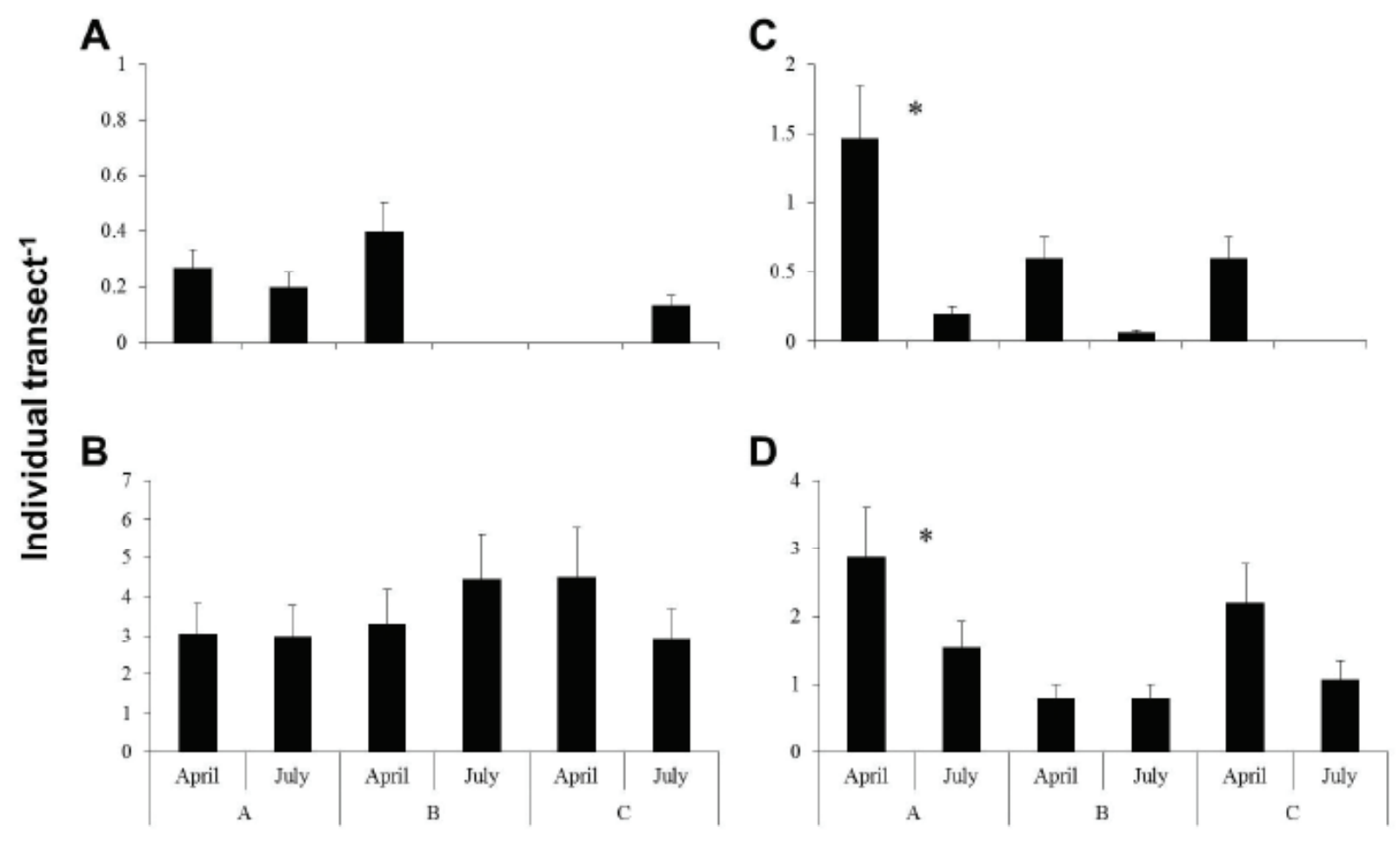

Site 
Previously, t was found that experimental removal of algae from around the juvenile corals could increase parrotfish predations of those corals [14]. It was suggested that coral camouflaging and creating microhabitats with lower graze rates were two mechanisms by which algae could protect juvenile corals against parrotfishes [14]. However, none of these appeals to the present study because the massive Porites colonies in this work, which in some cases were 2-3 $\mathrm{m}$ in size, could not be sheltered from fish predation by either camouflage or microhabitats. Thus, we have to consider other mechanisms before entertaining the idea whether macroalgae prevented fish predation of Porites corals at Qeshm Island.

\section{A}

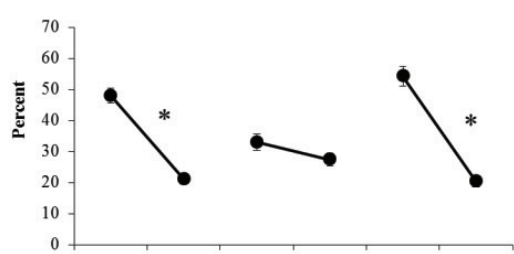

B

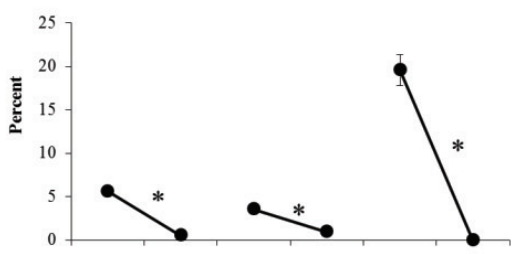

C

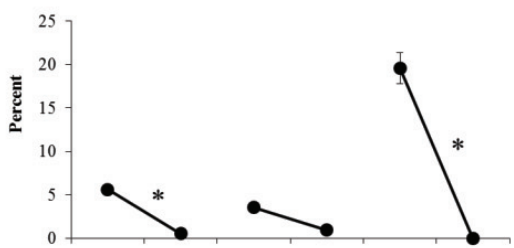

D

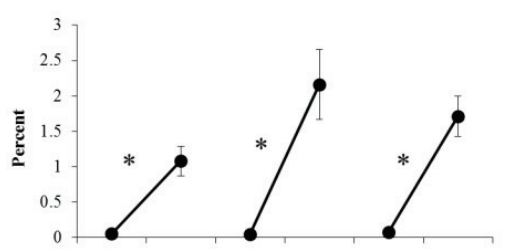

E

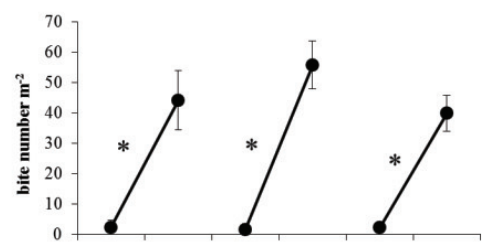

$\mathbf{F}$

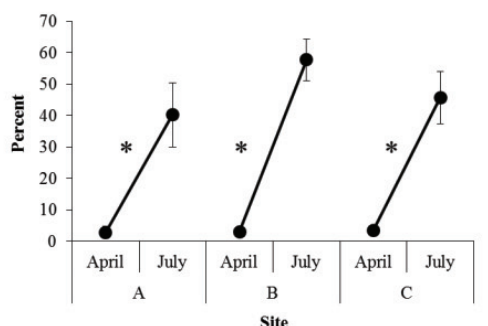

Figure 3: A) Algal cover (combined macroalgae (MA) and filamentous (FL) algae) B) MA cover C) FA cover D) live coral tissue grazed by parrotfish E) number of spot fish bite marks $\mathrm{m}^{-2}$ of live coral surface area F) percent Porites colonies with fish bite marks d) in April and July 2014 at three research sites. Error bars show standard errors. Asterisk show significant differences between sampling months.

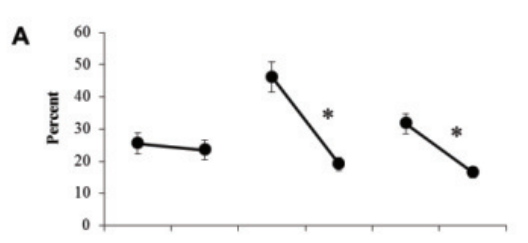

B
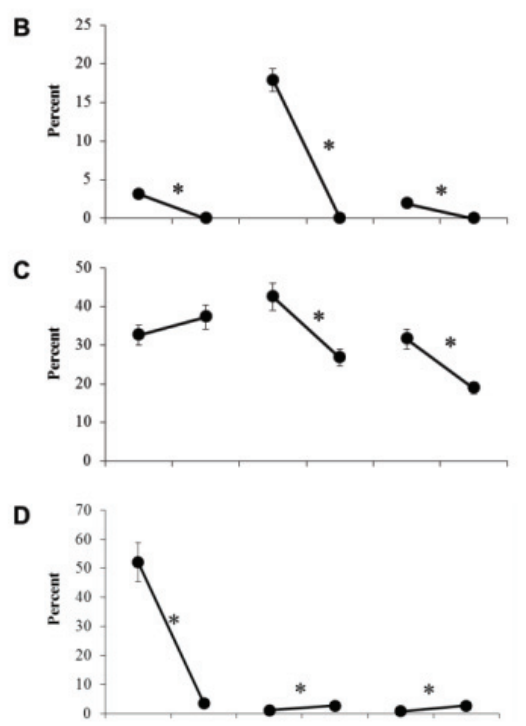

E
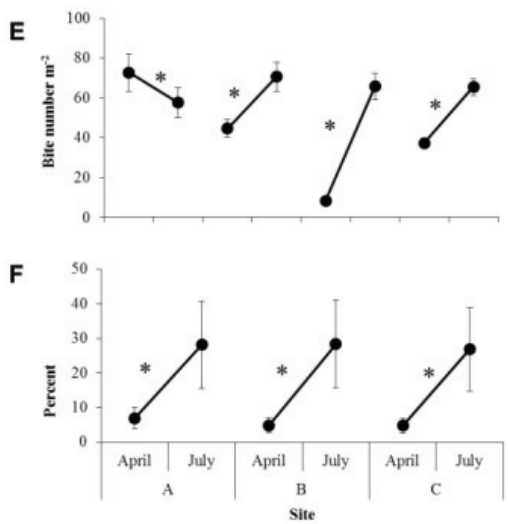

Figure 4: A) Algal cover (combined macroalgae (MA) and filamentous (FL) algae) B) MA cover C) FA cover D) live coral tissue grazed by parrotfish E) number of spot fish bite marks $\mathrm{m}^{-2}$ of live coral surface area F) percent Porites colonies with fish bite marks in April and July 2015 at three research sites. Error bars show standard errors. Asterisk show significant differences between sampling months.

\section{Increase in adult parrotfish number in July rather than in April}

It is shown that increase in the abundance of adult corallivore fishes usually leads to higher grazing on corals [12, 22,23]. In the present study, the unusual increases in fish bite marks on coral colonies and the number of grazed colonies at site $\mathrm{A}$ in April 2015 compared to July could be due to the significantly higher abundance of adult fishes of both species. On the other hand, in neither July 2014 nor July 2015, did fish abundance show changes compared to April. Therefore, we cannot relate the observed phenomenon to parrotfish abundance.

\section{Declining food resources increased corallivory}

Parrotfishes are essential to some coral reefs because they feed on macroalgae [10,11]. Bellwood \& Choat [24] showed 
that the majority of Scarus species in the Great Barrier Reefs consume epilithic algae. Carpenter, et al. [25] also reported that Scarus spp. in the Persian Gulf were mainly grazers on shallow benthic algae. However, neither the study by Carpenter, et al. [25] nor any other study presents any information on the diet of S. persicus. In spite of this, field observations confirm that this species seems to be a scraper (i.e. it takes a piece of substratum and its accompanying algae in each bite [26] and eats filamentous algae (P. Tavakoli-Kolour, pers. obsv). In September 2009, although macroalgae completely disappeared, short filamentous algae prevailed. Simultaneously, severe fish biting on more than $80 \%$ of the Porites colonies could be observed [17]. Filamentous algae are favorable food sources for herbivorous fish [28], and are more desirable, palatable and digestible than fleshy algae [27-29]. Therefore, high corallivory rates in September, when filamentous algae were abundant at the research locations, cannot be attributed to scarcity of food.

\section{Macroalgae prevented parrotfish grazing on Porites co- rals}

It has been proven that herbivorous coral reef fishes avoid dense macroalgae patches and prefer places with lower macroalgae [16]. Thus, if there are coral colonies among such dense macroalgae, they are most likely naturally protected from fish corallivory. In this study, there was no change in parrotfish distribution at any site between April and July, which suggests that macroalgae did not repel fish from the reefs. The increased

Table 1: Correlational analyses between algal cover (including AL, MA and FA cover) and fish grazing related factors (including $C C G=$ the overall area of live coral tissue which was grazed by parrotfishes, FBN= the frequency of fish bite marks on Porites colonies, and PCG= the percentage of Porites colonies grazed by parrotfishes, ) at site and transect levels in 2014. Significant results are shown in bold.

\begin{tabular}{|c|c|c|c|c|}
\hline \multicolumn{5}{|c|}{ Sites } \\
\hline & & CCG & FBN & PCG \\
\hline \multirow[t]{3}{*}{$\mathrm{AL}$} & Pearson Correlation & -0.744 & -0.798 & -0.796 \\
\hline & Sig. (2-tailed) & 0.90 & 0.057 & 0.058 \\
\hline & $\mathrm{N}$ & 6 & 6 & 6 \\
\hline \multirow[t]{3}{*}{ MA } & Spearman's rho & -0.600 & -0.600 & -0.657 \\
\hline & Sig. (2-tailed) & 0.208 & 0.208 & 0.156 \\
\hline & $\mathrm{N}$ & 6 & 6 & 6 \\
\hline \multirow[t]{3}{*}{ FA } & Pearson Correlation & -0.699 & -0.760 & -0.759 \\
\hline & Sig. (2-tailed) & 0.122 & 0.080 & 0.080 \\
\hline & $\mathrm{N}$ & 6 & 6 & 6 \\
\hline \multicolumn{5}{|c|}{ Transects } \\
\hline & & CCG & FBN & PCG \\
\hline \multirow[t]{3}{*}{$A L$} & Spearman's rho & -0.313 & -0.318 & -0.361 \\
\hline & Sig. (2-tailed) & 0.098 & 0.093 & 0.054 \\
\hline & $\mathrm{N}$ & 29 & 29 & 29 \\
\hline \multirow[t]{3}{*}{ MA } & Spearman's rho & -0.438 & -0.463 & -0.454 \\
\hline & Sig. (2-tailed) & 0.018 & 0.011 & 0.013 \\
\hline & $\mathrm{N}$ & 29 & 29 & 29 \\
\hline \multirow[t]{3}{*}{ FA } & Spearman's rho & -0.245 & -0.267 & -0.334 \\
\hline & Sig. (2-tailed) & 0.200 & 0.161 & 0.076 \\
\hline & $\mathrm{N}$ & 29 & 29 & 29 \\
\hline
\end{tabular}

Table 2: Correlational analyses between algal cover (including AL, MA and FA cover) and fish grazing related factors (including $C C G=$ the overall area of live coral tissue which was grazed by parrotfishes, FBN= the frequency of fish bite marks on Porites colonies, and PCG= the percentage of Porites colonies grazed by parrotfishes,) at site and transect levels in 2015. Significant results are shown in bold.

\begin{tabular}{|c|c|c|c|c|}
\hline \multicolumn{5}{|c|}{ Sites } \\
\hline & & CCG & FBN & PCG \\
\hline \multirow[t]{3}{*}{$\mathrm{AL}$} & Pearson Correlation & 0.029 & -0.314 & -0.314 \\
\hline & Sig. (2-tailed) & 0.957 & 0.544 & 0.544 \\
\hline & $\mathrm{N}$ & 6 & 6 & 6 \\
\hline \multirow[t]{3}{*}{ MA } & Spearman's rho & -0.314 & -0.086 & -0.657 \\
\hline & Sig. (2-tailed) & 0.544 & 0.872 & 0.156 \\
\hline & $\mathrm{N}$ & 6 & 6 & 6 \\
\hline \multirow[t]{3}{*}{ FA } & Pearson Correlation & 0.029 & -0.314 & -0.314 \\
\hline & Sig. (2-tailed) & 0.957 & 0.544 & 0.544 \\
\hline & $\mathrm{N}$ & 6 & 6 & 6 \\
\hline \multicolumn{5}{|c|}{ Transects } \\
\hline & & CCG & FBN & PCG \\
\hline \multirow[t]{3}{*}{$\mathrm{AL}$} & Spearman's rho & 0.139 & 0.255 & -0.151 \\
\hline & Sig. (2-tailed) & 0.464 & 0.174 & 0.425 \\
\hline & $\mathrm{N}$ & 30 & 30 & 30 \\
\hline \multirow[t]{3}{*}{ MA } & Spearman's rho & -0.365 & -0.127 & -0.624 \\
\hline & Sig. (2-tailed) & 0.047 & 0.505 & 0.000 \\
\hline & $\mathrm{N}$ & 30 & 30 & 30 \\
\hline \multirow[t]{3}{*}{ FA } & Spearman's rho & 0.200 & 0.270 & -0.016 \\
\hline & Sig. (2-tailed) & 0.290 & 0.149 & 0.934 \\
\hline & $\mathrm{N}$ & 30 & 30 & 30 \\
\hline
\end{tabular}

fish abundance at site A in April 2015 backs this hypothesis. Thus, the low fish bite rates in April must be attributed to other factors. For example, macroalgal cover might prevent fish from grazing on corals through other mechanisms, most likely producing chemicals, which are reported to exist in macroalgae [30]. Recently, it has been shown that both coral larvae and juvenile fishes of different species avoid waters with water soluble chemicals produced by macroalgae [31]. However, the mixed statistical results and low macroalgal cover at two sites in April in each year $(\sim 5 \%)$ bring up two other hypotheses that may be involved in the findings of this study.

\section{Increased water temperature increased corallivory}

Previous studies show that changes in water temperature can change the food intake rate [32-34]. Some studies show that increases in water temperature increase metabolism and nutrient requirement rate among fishes [34-37]. Water temperature obviously increases in the Persian Gulf in summer, which could explain the potential increase in graze rate by the fishes, which, however, did not happen. Indeed, there was a significant increase in the number of fish bite $\mathrm{min}^{-1}$ (only on algae) in Febrauray 2016, when it was cold. Despite this, even if there was an increase in fish grazing rates due to elevated temperatures, the reason(s) why there was a shift from the main food source of $S$. persicus (whatever kind it is) to corals may not be explained by increased seawater temperature. 


\section{Enhanced nutrient contents of Porites corals increased corallivory}

Parrotfishes selectively graze on nutrient-rich foods [38-40]. Rotjan \& Lewis [41-45] showed that parrotfishes selectively graze on high reproductive polyps within a single colony known to have higher nutritional values than nonreproductive polyps. Unfortunately there is no information on reproduction of Porites spp. (the focus of this study) in Qeshm Island. However, coral eggs were taken with a Neuston net on the $20^{\text {th }}$ of August 2009 and also on the $21^{\text {st }}$ of August 2011 somewhere between southeast of Qeshm Island (our studied site) and northwest of Larak Island (H. Rezai, personal communication). Personal observations at two other Iranian Islands (Kish and Larak Islands) suggest June and August as the peak months of spawning [42]. As no study has specifically monitored reproduction of Porites spp. in Qeshm Island, we cannot be certain about the exact month in which the highest proportion of colonies with mature oocytes peaked. Therefore, it is difficult to relate the increased corallivory to coral reproduction. However, the observed coral spawning in August makes it likely that Porites colonies were rich in nutrients in June/July and attracted parrotfishes.

This study brings up the hypothesis of the naturally protective role of macroalgae of adult corals against parrotfishes. This ecological process is an annual phenomenon happening among the southeastern reefs of Qeshm Island sometime in June, July or September of every year. Although there is some supporting data, this phenomenon is more likely to be related to enhanced corals' nutrition (or another factor), in particular, to the fact that the macroalgal cover was not dense enough to hide or somehow impact large coral colonies ( $5 \%$ at sites A and B in April 2014, and 5\% at sites A and C in April 2015). Therefore, the increased impacts of parrotfishes on Porites colonies while macroalgal cover decreased at Qeshm Island may be coincidental.

The coral colonies grazed by parrotfishes in September 2009 were found to have fully healed by November of the same year [17]; however, in our most recent study in August 2014, partial coral mortality due to fish biting was also observed, and in 2015, the grazed colonies were observed even in October. Therefore, healing is not always an option. To better understand this phenomenon, further investigation in particular at other reef sites is deemed necessary.

\section{References}

1. McCook L, Jompa J, Diaz-Pulido G (2001) Competition between corals and algae on coral reefs: a review of evidence and mechanisms. Coral Reefs 19 : 400-417. Link: https://bit.ly/365tdTm

2. McManus JW, Polsenberg JF (2004) Coral-algal phase shifts on coral reefs: ecological and environmental aspects. Progress in Oceanography 60: 263 279. Link: https://bit.ly/369bRF6

3. Birrell CL, McCook LJ, Willis BL (2005) Effects of algal turfs and sediment on coral settlement. Marine Pollution Bulletin 51: 408-414. Link: https://bit.ly/3lcHcel

4. Cheal AJ, MacNeil MA, Cripps E, Emslie MJ, et al. (2010) Coral-macroalgal phase shifts or reef resilience: links with diversity and functional roles of herbivorous fishes on the Great Barrier Reef. Coral Reefs 29: 1005-1015. Link: https://bit.ly/3m9QwRM

5. Bonaldo RM, Hay ME (2014) Seaweed-coral interactions: variance in seaweed allelopathy, coral susceptibility, and potential effects on coral resilience. Plos One 9: e85786. Link: https://bit.ly/365NGaD

6. Mumby PJ, Foster NL, Fahy EAG (2005) Patch dynamics of coral reef macroalgae under chronic and acute disturbance. Coral Reefs 24: 681-692. Link: https://bit.ly/377LGOY

7. Renaud PE, Riggs SR, Ambrose WG, Schmid K, Snyder SW (1997) Biologicalgeological interactions: storm effects on macroalgal communities mediated by sediment characteristics and distribution. Continental Shelf Research 17: 37-56. Link: https://bit.ly/3q2Vdiv

8. Humphries AT, McClanahan TR, McQuaid CD (2014) Differential impacts of coral reef herbivores on algal succession in Kenya. Marine Ecology Progress Series 504: 119-132. Link: https://bit.ly/2V59Zak

9. Hay ME (1997) The ecology and evolution of seaweed-herbivore interactions on coral reefs. Coral reefs 16: S67-S76. Link: https://bit.ly/39ciN6y

10. Rotjan RD, Lewis SM (2005) Selective predation by parrotfisheses on the reef coral Porites astreoides. Marine Ecology Progress Series 305: 193-201. Link: Link: https://bit.ly/39gtt3X

11. Mccauley DJ, Young HS, Guevara R, Williams GJ, Power EA, et al. (2014) Positive and negative effects of a threatened parrotfish on reef ecosystems. Conserv Biol 28: 1312-1321. Link: https://bit.ly/365FLtV

12. Bonaldo RM, Bellwood DR (2011) Parrotfishes predation on massive Porites on the Great Barrier Reef. Coral Reefs 30: 259-269. Link: https://bit.ly/2V3QrTD

13. Welsh JQ, Bonaldo RM, Bellwood DR (2014) Clustered parrotfish feeding scars trigger partial coral mortality of massive Porites colonies on the inshore Great Barrier Reef. Coral Reefs 34: 81-86. Link: https://bit.ly/2JfBXgG

14. Venera-Ponton DE, Diaz-Pulido G, McCook LJ, Rangel-Campo A (2011) Macroalgae reduce growth of juvenile corals but protect them from parrotfishes damage. Marine Ecology Progress Series 421: 109-115. Link: https://bit.ly/3o4eYV

15. Brandl SJ, Hoey AS, Bellwood DR (2014) Micro-topography mediates interactions between corals, algae, and herbivorous fishes on coral reefs. Coral Reefs 33: 421-430. Link: https://bit.ly/367Ro3N

16. Hoey AS, Bellwood DR (2011) Suppression of herbivory by macroalgal density: a critical feedback on coral reefs?. Ecology Letters 14: 267-273. Link: https://bit.ly/33k1mgr

17. Kavousi J, Seyfabadi J, Rezai H, Fenner D (2011) Coral reefs and communities of Qeshm Island, the Persian Gulf. Zoological Studies 50: 276-283. Link: https://bit.ly/3meM58o

18. Bruckner AW, Bruckner RJ, Sollins $P$ (2000) Parrotfishes predation on live coral: "spot biting" and "focused biting". Coral Reefs 19: 50-50.

19. Kohler KE, Gill SM (2006) Coral Point Count with Excel extensions (CPCe): a visual basic program for the determination of coral and substrate coverage using random point count methodology. Computers \& Geosciences-UK 32 1259-1269. Link: https://bit.ly/3I2siYc

20. Bonaldo RM, Bellwood DR (2008) Size-dependent variation in functional role of the parrotfish Scarus rivulatus on the Great Barrier Reef, Australia. Marine Ecology Progress Series 360: 237-244. Link: https://bit.ly/367PqQL

21. Bonaldo RM, Bellwood DR (2008) Size-dependent variation in functional role of the parrotfish Scarus rivulatus on the Great Barrier Reef, Australia. Marine Ecology Progress Series 360: 237-244. Link: https://bit.ly/37c6Jzs

22. Bruggemann JH, Van Kessel AM, Van Rooi JM, Breeman AM (1996) Bioerosion and sediment ingestion by the Caribbean parrot fish Scarus vetula

Citation: Kavousi J, Kolour PT, Kari SH (2020) Corallivory and algal dynamics on some coral reefs in the Persian Gulf. Glob J Ecol 5(1): 122-128. 
and Sparisoma viride: im placations of fish size, feeding mode and habitat use. Marine Ecology Progress Series 134: 59-71. Link: https://bit.ly/2HBuulq

23. Morgan KM, Kench PS (2016) Parrotfish erosion underpins reef growth, sand talus development and island building in the Maldives. Sedimentary Geology 341: 50-57. Link: https://bit.ly/3fBHme7

24. Bellwood DR, Choat JH (1990) A functional analysis of grazing in parrotfishes (family Scaridae): the ecological implications. Environmental Biology of Fishes 28: 189-214. Link: https://bit.ly/2KIFnti

25. Carpenter KE, Krupp F, Jones DA, Zajonz U (1997) Living marine resources of Kuwait, eastern Saudi Arabia, Bahrain, Qatar, and the United Arab Emirates. FAO, Rome. Link: https://bit.ly/33jb7Ma

26. Hoey AS, Bellwood DR (2008) Cross-shelf variation in the role of parrotfishes on the Great Barrier Reef. Coral Reefs 27: 37-47. Link: https://bit.ly/33gSuZ0

27. Kopp D, Bouchon-Navaro Y, Cordonnier S, Haouisée A, Louis M, et al. (2009) Evaluation of algal regulation by herbivorous fishes on Caribbean coral reefs. Helgoland Marine Research 64: 181-190. Link: https://bit.ly/3lgRg6t

28. Bruggemann JH, Begeman J, Bosma EM, Verburg P, Breeman AM (1994a) Foraging by the stoplight parrotfishes Sparisoma viride. II. Intake and assimilation of food, protein, and energy. Marine Ecology Progress Series 106 57-71. Link: https://bit.ly/39k07Qu

29. Hamilton SL, Smith JE, Price NN, Sandin SA (2014) Quantifying patterns of fish herbivory on Palmyra Atoll (USA), an uninhabited predator-dominated central Pacific coral reef. Marine Ecology Progress Series 501: 141-155. Link: https://bit.ly/39k06Mq

30. Rasher DB, Hay ME (2010) Seaweed allelopathy degrades the resilience and function of coral reefs. Commun Integr Biol 3: 1-4. Link: https://bit.ly/3m7L81z

31. Dixson DL, Abrego D, Hay ME (2014) Chemically mediated behavior of recruiting corals and fishes: A tipping point that may limit reef recovery. Science 345: 892-897. Link: https://bit.ly/3fzsFsf

32. Diaz-Pulido G, Garzon-Ferreira J (2002) Seasonality in algal assemblages on upwelling-influenced coral reefs in the Colombian Caribbean. Botanica Marina 45: 284-292. Link

33. Smith TB (2008) Temperature effects on herbivory for an Indo-Pacific parrotfish in Panama: implications for coral-algal competition. Coral Reefs 27: 397-405. Link: https://bit.ly/3nZtjlO

34. Afeworki Y, Zekeria ZA, Videler JJ, Bruggemann JH (2013) Food intake by the parrotfish Scarus ferrugineus varies seasonally and is determined by temperature, size and territoriality. Marine Ecology Progress Series 489: 213 224. Link: https://bit.ly/33jJYsj

35. Buentello JA, Gatlin III DM, Neill WH (2000) Effects of water temperature and dissolved oxygen on daily feed consumption, feed utilization and growth of channel catfish Ictalurus punctatus. Aquaculture 182: 339-352. Link: https://bit.ly/39grRap

36. Person-Le Ruyet J, Mahé K, Le Bayon N, Le Delliou H (2004) Effects of temperature on growth and metabolism in a Mediterranean population of European sea bass, Dicentrarchus labrax. Aquaculture 237: 269-280. Link: https://bit.ly/3q0fyoB

37. Katersky RS, Carter CG (2007) High growth efficiency occurs over a wide temperature range for juvenile barramundi Lates calcarifer fed a balanced diet. Aquaculture 272: 444-450. Link: https://bit.ly/2J3MbkS

38. Bruggemann JH, Van Oppen MJ, Breeman AM (1994b) Foraging by the stoplight parrotfish Sparisoma viride I. Food selection in different, socially determined habitats. Marine Ecology Progress Series 106: 41-55. Link: https://bit.ly/3o2eizp

39. Crossman DJ, Choat JH, Clements KD (2005) Nutritional ecology of nominally herbivorous fishes on coral reefs. Marine Ecology Progress Series 296:129142. Link: https://bit.ly/2V58gBS

40. Goecker ME, Heck KL, Valentine JF (2005) Effects of nitrogen concentrations in turtlegrass Thalassia testudinum on consumption by the bucktooth parrotfish Sparisoma radians. Marine Ecology Progress Series 286: 239-248. Link: https://bit.ly/3fym29y

41. Rotjan RD, Lewis SM (2009) Predators selectively graze reproductive structures in a clonal marine organism. Marine Biology 156: 569-577. Link: https://bit.ly/3fBzg5f

42. Howells EJ, Abrego D, Vaughan GO, Burt JA (2014) Coral spawning in the Gulf of Oman and relationship to latitudinal variation in spawning season in the northwest Indian Ocean. Sci Rep 4: 7484. Link: https://go.nature.com/2Je7foi

43. Bauman AG, Baird AH, Cavalcante GH (2011) Coral reproduction in the world's warmest reefs: southern Persian Gulf (Dubai, United Arab Emirates). Cora Reefs 30: 405-413. Link: https://bit.ly/2J3LJDc

44. Cole AJ, Pratchett MS, Jones GP (2008) Diversity and functional importance of coral-feeding fishes on tropical coral reefs. Fish and Fisheries 9: 286-307. Link: https://bit.ly/316ysXh

45. Rizzari JR, Frisch AJ, Hoey AS, McCormick MI (2014) Not worth the risk: apex predators suppress herbivory on coral reefs. Oikos 123: 829-836. Link: https://bit.ly/365FXcl

Discover a bigger Impact and Visibility of your article publication with Peertechz Publications

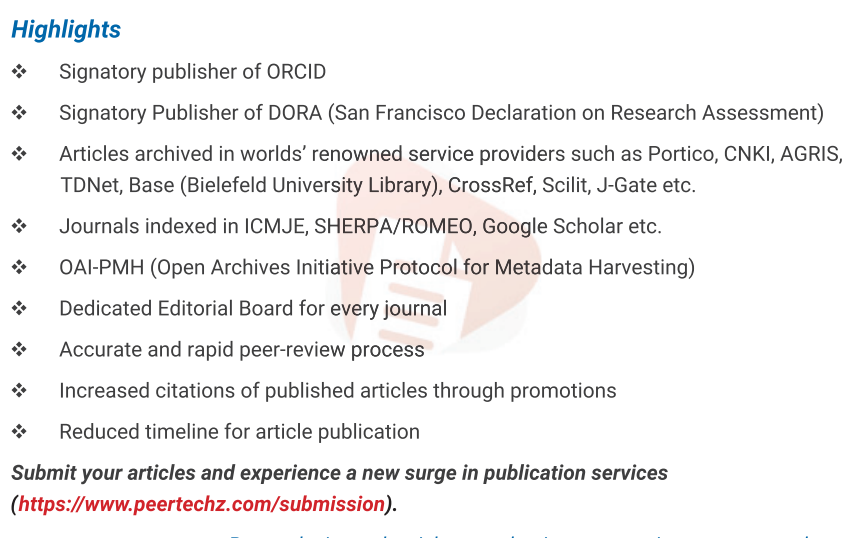

Peertechz journals wishes everlasting success in your every endeavours.

Copyright: @ 2020 Kavousi J, et al. This is an open-access article distributed under the terms of the Creative Commons Attribution License, which permits unrestricted use, distribution, and reproduction in any medium, provided the original author and source are credited.

Citation: Kavousi J, Kolour PT, Kari SH (2020) Corallivory and algal dynamics on some coral reefs in the Persian Gulf. Glob J Ecol 5(1): 122-128. DOI: https://dx.doi.org/10.17352/gje.000031 